\title{
The Impact of China-Africa Trade on Industries in Africa: A Case Study of FOCAC and BRI
}

\author{
Reginald Masimba Mbona (Corresponding author) \\ School of Finance and Economics, Jiangsu University \\ No. 301 Xuefu Road, Zhenjiang, Jiangsu, P.R. China \\ E-mail: rmmbona@yahoo.com
}

Received: April 24, 2021 Accepted: May 26, 2021 Published: June 1, 2021

doi:10.5296/ber.v11i2.18556 URL: https://doi.org/10.5296/ber.v11i2.18556

\begin{abstract}
Over the last two decades, the trade between Africa and China has grown significantly but there is still a debate on how local industries in Africa are being affected. Two key foreign policies, FOCAC and BRI, by China are the foundations on which the trade is done with its African partners. This study aims to assess which industries in Africa are being affected by these Chinese-led foreign trade policies and the significance of that impact. Using panel data, the study examines the effect of the FOCAC era and the FOCAC+BRI era on the energy, agriculture, mining, manufacturing, and technology industries for six partners. The results from the analysis showed that imports positively affect the agriculture and the energy sectors while the manufacturing industry is negatively affected by imported goods. On the other hand, exports have shown a positive impact on the mining sector. However, the agriculture industry is still struggling to have positive gains from exports. The findings of this study are important as the continent works towards "One Africa" which seeks to promote sustainable development of the continent. Also, the study focuses on specific industries that are significant to the economic growth of these countries as shown by their positive relationship with the GDP of these nations.
\end{abstract}

Keywords: FOCAC, BRI, Trade flows, Panel regression, Industrial development, Trade policies

\section{Introduction}

\subsection{Background}

Over the last two decades, there has been a surge in the quantities of "Made in China" products in African countries. With the two parties strengthening their ties, it is anticipated that this will even grow higher. The introduction of the Forum for China - Africa Cooperation 
(FOCAC) in 2000 was a gateway that was opened to increase the flow of trade between these two partners. Even though the package of FOCAC included other items like aid, financial assistance, and investment flow the main driver of this has been trading. China having high manufacturing output has been in search of global markets and Africa is one of the markets with high potential to buy their products.

The continent including the six countries in this study, Algeria, Egypt, Kenya, Ghana, Nigeria, and South Africa, is very rich in natural resources which are well distributed not only across the whole continent but even in individual countries. These include mineral deposits, rich agricultural lands, high crop output, metals, and oil. With a fast-growing economy that rose in a short space of time to be a global economic giant, such resources are needed to sustain the economic growth and to supply the ever-rising demand from the Chinese market.

In 2013 the Chinese government took a further step to increase their trade by reviving the ancient Silk Road which was a trade route that linked them to Europe and the Middle East. Now this modern version has been developed to also include African countries. Such a move is seen as an additional policy that will further increase the trade between China and Africa as well. Since 2013, the continent has therefore been a beneficiary of two major Chinese foreign trade policies namely the FOCAC and the Belt and Road Initiative (BRI). This makes trade a very important component of these countries especially given how China steadily over the past decades grew to become the highest trade partner for the continent.

With this in mind, this study focuses on examining the effect of this on the local strategic or key industries. As proposed by (Tsokalida \& Jun, 2019) we carry out an investigation on which sectors the impact of trade is transmitted in African countries. This is a very important step in assessing how beneficial this trade has been to the continent. The local industries in this study are the energy sector, the manufacturing industry, the agriculture sector, the mining sector, and the technology industry which (Tang \& Gyasi, 2012; Yu, Qian, \& Liu, 2019) in their studies separately consider as key industries to be focused on as they need the most development and have the highest demands at the present moment in Africa. These have been key talking points when the trade with China is mentioned not only within the continent but it has even been discussed by other countries who see the growing influence of China on the continent as a threat to their existing trade relations with the countries (Anedo, 2012; Busse, Erdogan, \& Mühlen, 2016; Monson \& Rupp, 2013).

The study has also used the model of "One Africa" which was adopted by the Africa Union in November 2015. This is very important especially given how the foreign policies coming from China target the whole region as evidenced by how the country regularly summon the FOCAC meeting with a majority of Africa's head of states and some of their diplomats. It is therefore very important that as Africa look into the future and how to build towards it, research also has to adopt this in following what African leaders started as they welcome partners to the continent. Even though they remain as individual countries a united voice in policy formulation is what is needed to solve the problems that are "universal" to all the countries. Some past studies have looked at individual countries and other industries but this study is set up to assist in how best the One Africa movement can be used to maximize 
benefits from trade in the selected industries through designing of One Policy which will promote the interests of local industries in a sustainable way.

Bilateral agreements remain key in building trade relations between these two partners. The treaties that are signed are the driving tools that set the tempo and the direction in which the trade goes. They also set limits of what can be traded and how it is traded. The literature so far has had mixed results even for the same country as they have failed to reach a conclusive assessment on the effects of trade leaving room for more investigation. With most papers so far focusing on FDI flow from China (Busse et al., 2016; Gagne, 2018; Tang \& Gyasi, 2012), trade has been neglected making this study timely for Africa especially as it works on mapping its recovery strategy after the Covid-19 pandemic. Additionally, Africa by proportion to other regions still constitute a small proportion of the trade value for China making them a region of lesser interest to Chinese scholars hence on both ends there hasn't been much done on the area of trade especially given the impact of these two key foreign policies.

One of the major issues that are faced by the continent is that there has not been a consistent and solid policy towards the growing partnership with China (Aly, 2019; Drummond \& Liu, 2015; Zoumara \& Ibrahim, 2013). The terms of everything seem to come from the Chinese who are the architects of both policies under study. This is a worrying status in a relationship that is said to be based on mutual values in terms of cooperation, development, and trust built with the mind of win-win deals at all times. With Africa now pursuing the deals on the terms and conditions of Chinese counterparts their bargaining power is weak which is likely to affect industries and this study seeks to investigate how it has affected the domestic industries. We first look at the period between 2002-2012 when there was only the FOCAC in operation and then the period 2013-2019 when the BRI was introduced to see how its combination with FOCAC has been affecting local industries. Furthermore, this study seeks to prove the truth in the notion that this relationship can unleash the potential Africa has in terms of building their industries and developing their economies (Asante, 2018).

\subsection{Forum for China - Africa Cooperation FOCAC}

Towards the end of the year 2000, China launched the FOCAC which was a policy that had been designed specifically for Africa. Trade was one of the main focal areas of this policy. The vision was built around the South-South cooperation in which developing countries build each other's economies through activities that promote development and economic growth. During the first era when FOCAC existed as the only major policy towards Africa we saw the following major developments:

1) Establishment of Chinese owned industrial plants with some being co-owned with local companies

2) Building of special economic development zones that served as main operation centers for the big companies wanting mostly free zone for operation in the continent

3) Construction of China cities especially in major towns of every country with the main goal of promoting small businesses in their trade 
4) Engagement of private firms and government firms both small and big in the activities that promoted the goals of FOCAC

5) Removal of many trade barriers and tariffs to make the trade process smooth and favorable

6) High flow of bottom of pyramid FMCG goods with low cost from China to Africa

7) The flow of capital goods and high-tech equipment

Even though this has been contributing to economic growth, the effect on industries by sector remains something to be investigated.

\subsection{Belt and Road Initiative BRI}

To further advance their foreign policy and strengthen their economic power, China revived the ancient Silk Road into the Belt and Road Initiative. The new trade route covers Europe, Asia, and Africa. Trade and improvement of trade logistics are the key issues that it aims to address (Zhai, 2018). Africa has already been benefiting from this as proved by various railway lines linking countries and ports, Mombasa-Nairobi Standard Gauge Railway, Kenya, Ethiopia-Djibouti railway, Lobito-Luau railway, Angola, Abuja-Kaduna railway, Nigeria.

As China is currently having an excess manufacturing capacity, they needed new markets for their products and new operating regions for their growing companies. Even though not all African countries are part of the BRI the continent has been included mainly through the coastal countries which are seen as the major entry points into the continent which one of the major reasons behind the countries selected.

Through the BRI we have seen the following being accomplished in the short time it has been in operation

1) Increased in Chinese funded construction

2) Increase in the trade volumes

3) Building of coastal countries as strategic entry points into the continent

4) Higher aid flow

5) The new model of payment for trade in form of none financial payments or swap deals

It is important that as BRI is still in its early stages and also with the One Africa being pursued, the continent comes up with its strategy to complement what has already been started by the Chinese so that they maximize the benefits and the returns. The existence of this friendship over the years is proof of the loyalty in this friendship which gives an assurance that the policies can improve the continent's industrial state.

As we examine the combination of these two policies the study will lay down a foundation to be used in further studies as well as in policy-making especially as it has been noted already that aside from academic literature, data and statistics remain a challenge making it difficult and complex for those who work in the policy formation. 
The rest of the study is arranged as follows: the second section reviews the literature that leads into the hypothesis development. This is followed by the methodology and then the presentation and discussion of the study. The last section concludes the research.

\section{Literature Review}

In a study by (He, 2013) which is the transition year for the two policies, it was found that Chinese trade had a considerably stronger relationship with the economy as compared to the ones from other partners which were contending for the control of the region's trade. The argument was that the South-South trade yielded better results for the countries. This, therefore, means that it is expected that this also applies to the other industries as the study only focused on the manufacturing industry.

Another very important study by (Harlies, 2019) supported the notion of how China is selective in the countries to engage in and how to partner with them. This is very true especially as we look at the model of the BRI which has mostly been implemented in coastal countries (Biswas \& Tortajada, 2018). This is a strategic move which this study propose has an effect to boost trade and even improve the benefits that are being enjoyed by the local industries in these countries and the rest of the continent. The outcome of this research will prove if truly the interests of local industries are being protected and considered in trade deals.

In justifying why different partners seem to have different treatment (Mhaka \& Jeke, 2018) propose that the market size of the partner affects the amount of trade. To add to it they also suggest that the economic condition of the country is determinant in the spending habits of the customers as well as in the assurance of returns which are also important factors considered when a destination is picked. Even though these two are not the only factors considered in trade they seem from the distribution of Chinese establishments in trade to be well considered as the segments are designed including in the six countries which are some of the top economies in Africa.

Africa is well known for its rich natural resources (Drummond \& Liu, 2015; Habiyaremye, 2016; Lyons, Brown, \& Li, 2013) which are essential in any country which wants to sustain their economy especially when it is mostly built around high manufacturing activities. Over the past years, the continent has been seen as the source of cheap raw materials for production which ended up hurting its industry as gains were suppressed by the unfavorable trade terms. This study takes key sources of raw materials which are the agriculture and the mining sector, to examine how these two are being affected by trade to ensure that they do not suffer the same fate from the previous deals as measures will be taken to promote, protect and develop them.

The existence of a very strong political relationship between China and most of the ruling parties in Africa cannot be taken for granted. Such a relationship is one of the major reasons why many countries have been willing to participate in the activities organized by China which include their "China hosted Africa Union" meetings held under FOCAC. Also, there has been a look East policy implemented in most of the countries which are meant to promote 
tread with mainly Russia and China. This role by politics aids to the other factors like cheaper products, better terms of trade, no interest on loans, and alternative payment models that come from China. With leaders wanting the best for their parties to remain in power we anticipate that this relationship will be used as a way to ensure that the trade benefits the local industries that prove their effectiveness (D. N. Mlambo, Mlambo, \& Mubecua, 2018).

The question of sustainability of the trade relations remains a big puzzle especially give how they are growing at a faster rate than any other relationships Africa had with a single government (Titiloye Ademola, Bankole, \& Adewuyi, 2009). There is a need to therefore evaluate how this trade especially is affecting the long-term gains of the continent beyond the immediate gains, losses, and spillovers from the trade. Examining the effect these imports and exports have on the local industry is key since industrial growth is one element needed for a sustainable economy in the future. The results from the study can be used as one tool to guide negotiations on trade terms that will be good for the long-term future especially the future beyond the political cycles which are usually 5 years.

Due to the overwhelming growth in the local industries and the domestic economy, the Chinese have been encouraging their companies to go global. The government has been actively creating platforms for new markets as well as new partnerships for their companies. This has been one of the major factors behind the rapid increase in the trade between the two. However, even though this is good for the Chinese counterparts the benefits do not necessarily replicate for the African market. The fact that both imports and exports have been on the rise makes it more interesting to find out how much is influencing industrial development (Anedo, 2012).

Trade has also been boosted by the initiative in which there is trade paid for by resources on the continent. This has been viewed as a very great relief to the continent that was being constrained from engaging in further trade due to high debt. The model quickly attracted a lot of government-backed deals in which the government uses various resources at their disposal in swap trade deals. Even though this has been questioned in terms of its fairness the fact that it has worked as an alternative for trade has been seen to yield good economic results (Drummond \& Liu, 2015). However, there is a need to examine how this has affected the industries in concern. Mostly the mining and the agriculture sector are the ones involved in payment deals for trade hence we examine them (Habiyaremye, 2016).

The availability of relatively cheaper goods especially for households (consumables) and other technical equipment and gadgets has been very high in the trade. Literature has a mixed response to these: some argue that they have been beneficial especially to those in low-income countries and it has also offered healthy competition to the market (C. Mlambo, Kushamba, \& Simawu, 2016) this school thought justifies further importing of these. However, on the other hand, others are of the view that these are hurting the local industries whose cost of production is too high to meet the lower price range of the competing products (Geda, 2006). As this study looks at how the trade has affected both manufacturing and technology industries, it is anticipated that this tradeoff is also evaluated.

Another key area of concern is that the trade is viewed as unequal (Van Staden, Alden, \& Wu, 
2018) due to the inequality in the relationship. However many of the authors are of the view that this is not to be put on the Chinese (Foo, Lean, \& Salim, 2019) but rather the responsibility is on African Heads of States. There has not been an organized policy formation that is targeted at how to deal with the Chinese from the perspective of Africa. Even though each country may have its policies the fact that the whole continent is summoned by China for a conference shows how China sees the continent as one rather than as individual countries. Their policy on Africa is to encourage a united approach towards this partnership. Even though it will not be universal for all countries but it should be able to be the blueprint for the whole continent.

One of the major constraints that were affecting the trade and development of most industries in Africa is the transport and logistics industry which has been lagging for a long time (Chen, Xu, \& Haralambides, 2019; Dai \& Xu, 2013; Guo \& Shen, 2016). The Chinese have been working hard to improve this by actively engaging in the development of railway lines, airports, seaports, and highways. Even though this is mostly for the interest of their trade and part of it as a payment for various claims in natural resources the spillover of this development is felt not only in one economy but in many economies. For example, the construction of the Ethiopia- Djibouti railway has successfully linked two countries. Already these have improved their trade as they have a better and efficient model of transport for the consignments.

The high demand for capital goods has been influential in the growth of trade. These come as the continent is having a lot of start-ups and is encouraging the growth of SMEs and expansion of established industries (Esterhuyse \& Burgess, 2014; G. Wang et al., 2018). This is likely to impact the industries as they get more equipment to improve their production and productivity. The fact that China offers cheaper alternatives makes them an attractive source for the locals venturing into capital-intensive sectors.

In assessing how the trade has affected the textile industry of Ghana (Ibrahim, 2017) found that there has been a positive impact from the trade even though there is a risk that the local industry is beaten by the cheaper alternatives. However, the Ghana economy seemed to have its manufacturing affected by the substitutes from China which has led to the closure of many industries as noted by (Ibrahim, 2018). This study differs from these two in that it considers more than one country something that literature has pointed to be a need (Tsokalida \& Jun, 2019).

The literature is summarized in the following outstanding five factors that lead us to the development of the hypotheses of each industry:

- The effect of treaties (FOCAC and BRI) on trade's contribution to industries

- The effect of increased trade volume on local industries as additional trade policies are introduced

- The effect of the role of each country in the production value chain in getting the best gains from trade 
The significance of the swap deals on trade's relationship with local industry attached therein

\section{Hypothesis Development}

\subsection{Energy Industry}

The energy sector is one of the most important industries on the continent. Over the years the continent has struggled with access to electricity with at most just over $50 \%$ of the population having access to electricity. Some of the reasons for this include expensive machinery and equipment. With the coming of trade with the Chinese, it is expected that this industry benefits especially from the imports of such machinery since they offer way cheaper alternatives. In addition to that, it is expected that there will be an increased purchase of other renewable sources of energy especially solar panels which are mostly sourced from China at lower costs. This brings us to the hypotheses on the energy industry:

$\mathrm{H}$ : Imports are positively related to the electricity sector

$\mathrm{H}$ : Exports have no relationship with electricity

\subsection{Manufacturing Industry}

The continent has a very unstable manufacturing sector which has three major challenges of high production cost, shortage of capital, and then shortage of advanced technologies or equipment. With the coming of the capital goods from China, there has been a new flow of advanced machinery at very affordable prices and this has resulted in the reduction of the cost of running businesses as well as production. Besides, there has been a lot of intermediate goods flowing from China that are used in the industries where they are assembled into finished products. On top of this, the manufacturers on the continent have increased chances to export their products into niche markets in China. This boosts the manufacturing sector as there is a bigger market for them. However, the imports of finished goods have the potential to negatively affect the local industries especially when the rules for the competition are not clearly outlined by the local governments. This study predicts that the benefits from the imported capital goods outweigh the shortcomings from the finished products bringing an overall gain to the manufacturer. This sets up the hypotheses for the manufacturing industry:

H: Imports are positively related to the manufacturing industry

$\mathrm{H}$ : Exports are positively related to the manufacturing sector

\subsection{Agriculture Industry}

The agriculture industry remains key in a continent with vast lands and forests. According to (Habiyaremye, 2016), "Natural resources endowment is the most salient reason why an economy may have a large share of primary commodities in its exports." The coming of trade is good news for this sector as it brings much-needed foreign buyers for the products. Governments have in some cases even gone ahead to offer incentives to those who export their agricultural products. On the other hand, imports also come in handy for the equipment that is needed by the farmers. These range from tractors, planters, harvesters, irrigation 
equipment, and many other advanced technologies used in farming. Because they are cheaper in China, farmers have been using the Made in China branded equipment a lot. This gives us the hypotheses for the agriculture industry:

H: Imports are positively related to the agriculture industry

$\mathrm{H}$ : Exports are positively related to the agriculture industry

\subsection{Technology Industry}

These are technical goods that are used either for consumption by final consumers or in the production of other goods (Havrlant \& Hušek, 2011; K. Wang, Gou, Sun, \& Yue, 2012). The rate at which an economy imports and exports shows how much innovative the country is: with its exports showing their advantage over others in producing technically advanced goods and the imports showing how the country is still lagging at the same time how much it is investing towards advancing their technology. The industry has been having very high demand in Africa where the domestic manufacturers have not been able to fully satisfy the needs of the markets and also where the market always gives preference to cheaper products. Africa has mostly been dependent on imports in this industry with most of the products being manufactured outside the continent and a few being assemble there while just a handful are locally manufactured and exported. This leads us to the hypothesis on the technology industry:

$\mathrm{H}$ : Imports are positively related to the technology industry

$\mathrm{H}$ : Exports are negatively related to the technology industry

\subsection{Mining Industry}

The minerals and metals in Africa remain the biggest source of foreign currency for the countries and some of their most traded products are in this industry (Rahman, Majidi, Huwaina, Harun, \& Kasuma, 2017). It is beyond any doubt that these minerals have a significant impact on the economy. Two important things are considered for this impact to take effect: firstly, the volume of minerals traded has to be very high. Secondly, the value at which they are sold is very important to maximize the gains. There is always a need for more bidders for the miners to improve their bargaining power and China offers that competition to traditional buyers. In addition to this, the Chinese have engaged in investments in mines with the minerals taken straight back to their country which is a plus to the trade. Furthermore, the equipment which is coming from China like in other industries is very affordable which makes it affordable to invest in mines hence more players including the local ones venture into it. The swap deals, where mineral claims are used to pay for construction projects or loans extended are an additional boost to the trade of the minerals as these are also recorded as minerals traded (Bodomo, 2019). This gives us our hypotheses on the mining industry:

$\mathrm{H}$ : Imports are negatively related to the mining industry

$\mathrm{H}$ : Exports are positively related to the mining industry 


\section{Macrothink}

\section{Methodology}

\subsection{Time of Study}

The study looks at two time periods which are defined by the key economic policies which were implemented by the Chinese Government. The first period is the one under the FOCAC agreement from 2002-2012. The study left out the first two years of FOCAC due to a lack of data. It is then followed by the current era in which there is a combination of the BRI and the FOCAC being concurrently implemented in trade-related issues with Africa. Even though the OBOR hasn't been running for a period long for conclusive evaluation, the study sets up a preliminary analysis to guide adjustments especially on policies that make Africa ready to maximize their gains.

The quantitative data used in this study has been obtained from the World Integrated Trade Solutions and the World Bank data bank.

\subsection{Data Analysis Model}

The stud uses the panel model as was also supported by the following papers (Adeline \& Moussa, 2020; Bulletin, 2017; Burinskiene, 2012; Kea et al., 2019; Kilic, Yusecan, \& Ozekicioglu, 2019; Moussa, 2019; Sen, 2010; Taylor, 1986) among others.

The panel data linear model:

$$
Y=\beta_{0}+\beta_{1} X_{1}+\beta_{2} X_{2}+\beta_{3} X_{3}+\beta_{4} X_{4}+\ldots \beta_{n} X_{n}+\varepsilon
$$

Where; $\boldsymbol{Y}$ is the dependent variable, $\boldsymbol{\beta}_{\mathbf{0}}$ the constant, $\boldsymbol{\beta}_{\mathbf{1}}, \boldsymbol{\beta}_{\mathbf{3}}, \boldsymbol{\beta}_{\mathbf{4}}$, is the average change in $\boldsymbol{Y}$ that is associated with a unit change in $\boldsymbol{X}$ the independent variables while, $\boldsymbol{\varepsilon}$ is the random error.

Several benefits led this study to pick panel data in its analysis of the factors (Adeline \& Moussa, 2020; Hammon \& Zinn, 2020):

- It can model both individual and common behaviors in a group of data.

- It contains more information, more efficiency, and variability compared to the usual time series or cross-sectional data.

- The ability of panel data to not only measure but also detects significant effects and act as modified time series analysis

- In cases of biases that arise from aggregating groups into a single time series, pane data can minimize these

In running the regression we followed the recommendation by (Hill, Davis, Roos, \& French, 2019) in a review of literature on the use of panel data to run both the random effect and fixed effect followed by the Hausman test to decide which of the results to adopt for the study.

The study modified the model to suit our model as follows to incorporate our variables.

$$
\text { InIndustry }=\beta_{0}+\beta_{1} \operatorname{InImp}_{1}+\beta_{2} \operatorname{InExp}_{2}+\beta_{3} \operatorname{Inf}_{3}+\beta_{4} \operatorname{InFDI}_{4}+\beta_{5} \operatorname{InGDP}_{5}+\varepsilon
$$




\section{1) Macrothink}

Business and Economic Research

ISSN 2162-4860

2021, Vol. 11, No. 2

Variable definition

Independent variable: InIndustry is the log of one five industries (energy, agriculture, manufacturing, mining, and technology),

Dependent Variable: InImp is log of imports, InExp is log of exports,

Control Variables: Inf is Inflation, InFDI is log foreign direct investment, InGDP is log GDP.

\subsection{Descriptive Statistics}

Tables 1 and 2 show the descriptive statistics before and after OBOR. In both periods imports remained higher than exports based on the average for the two periods. It is also important to note that exports have the highest range which is a sign of the continent's general stable trend of importing. In Tables 3 and 4 we have the correlation analysis which has shown that there is no multicollinearity as the variables are not showing a significant relationship hence all the variables can be used in the regression model.

Table 1. Descriptive statistics FOCAC

\begin{tabular}{|l|l|l|l|l|l|}
\hline Variable & Obs & Mean & Std. Dev. & Min & Max \\
\hline inf & 77 & 8.82 & 5.25 & -0.69 & 26.67 \\
\hline inimp & 77 & 9.48 & 0.57 & 8.26 & 10.79 \\
\hline inexp & 77 & 8.79 & 1.06 & 6.76 & 11.00 \\
\hline inagr & 77 & 10.24 & 0.55 & 9.34 & 11.42 \\
\hline inele & 77 & 2.73 & 0.53 & 2.01 & 3.69 \\
\hline intech & 77 & 7.17 & 0.69 & 5.61 & 8.60 \\
\hline infdi & 77 & 9.31 & 0.80 & 7.33 & 10.66 \\
\hline ingdp & 77 & 11.10 & 0.59 & 9.79 & 12.21 \\
\hline inman & 77 & 10.55 & 0.65 & 9.19 & 11.68 \\
\hline inmin & 77 & 10.41 & 1.35 & 6.92 & 12.62 \\
\hline
\end{tabular}

Table 2. Descriptive statistics FOCAC+BRI

\begin{tabular}{|l|c|l|l|l|l|}
\hline Variable & Obs & Mean & Std. Dev. & Min & Max \\
\hline inf & 49 & 8.89 & 5.43 & 2.92 & 29.51 \\
\hline inimp & 49 & 9.99 & 0.42 & 9.23 & 10.90 \\
\hline inexp & 49 & 9.35 & 0.97 & 7.58 & 11.04 \\
\hline inagr & 49 & 10.50 & 0.51 & 9.82 & 11.47 \\
\hline inele & 49 & 2.80 & 0.51 & 2.15 & 3.63 \\
\hline intech & 49 & 7.93 & 0.44 & 7.32 & 8.88 \\
\hline infdi & 49 & 9.57 & 0.51 & 8.59 & 10.65 \\
\hline ingdp & 49 & 11.39 & 0.47 & 10.69 & 12.26 \\
\hline inman & 49 & 10.83 & 0.49 & 10.00 & 11.70 \\
\hline inmin & 49 & 10.87 & 1.18 & 8.43 & 12.65 \\
\hline
\end{tabular}


Table 3. Correlation analysis FOCAC

\begin{tabular}{|l|l|l|l|l|l|l|l|l|l|l|}
\hline & inf & inimp & inexp & inagr & inele & intech & infdi & ingdp & inman & inmin \\
\hline inf & 1.00 & & & & & & & & & \\
\hline inimp & -0.13 & 1.00 & & & & & & & & \\
\hline inexp & -0.24 & 0.74 & 1.00 & & & & & & & \\
\hline inagr & 0.00 & 0.59 & 0.46 & 1.00 & & & & & & \\
\hline inele & -0.33 & 0.27 & 0.41 & -0.02 & 1.00 & & & & & \\
\hline intech & -0.12 & 0.73 & 0.66 & 0.56 & 0.31 & 1.00 & & & & \\
\hline infdi & -0.05 & 0.68 & 0.58 & 0.60 & 0.16 & 0.57 & 1.00 & & & \\
\hline ingdp & -0.20 & 0.78 & 0.77 & 0.64 & 0.28 & 0.71 & 0.64 & 1.00 & & \\
\hline inman & -0.25 & 0.76 & 0.77 & 0.60 & 0.27 & 0.72 & 0.60 & 0.68 & 1.00 & \\
\hline inmin & -0.18 & 0.58 & 0.63 & 0.21 & 0.47 & 0.54 & 0.45 & 0.47 & 0.48 & 1.00 \\
\hline
\end{tabular}

Table 4. Correlation analysis FOCAC+BRI

\begin{tabular}{|l|l|l|l|l|l|l|l|l|l|l|}
\hline & inf & inimp & inexp & inagr & inele & intech & infdi & ingdp & inman & inmin \\
\hline inf & 1.00 & & & & & & & & & \\
\hline inimp & 0.22 & 1.00 & & & & & & & & \\
\hline inexp & -0.21 & 0.60 & 1.00 & & & & & & & \\
\hline inagr & -0.06 & 0.33 & 0.09 & 1.00 & & & & & & \\
\hline inele & -0.20 & 0.22 & 0.25 & -0.26 & 1.00 & & & & & \\
\hline intech & -0.06 & 0.57 & 0.35 & 0.54 & 0.06 & 1.00 & & & & \\
\hline infdi & 0.07 & 0.50 & 0.50 & 0.29 & 0.15 & 0.47 & 1.00 & & & \\
\hline ingdp & -0.24 & 0.69 & 0.50 & 0.57 & 0.14 & 0.76 & 0.48 & 1.00 & & \\
\hline inman & 0.20 & 0.61 & 0.56 & 0.44 & 0.21 & 0.65 & 0.58 & 0.75 & 1.00 & \\
\hline inmin & -0.07 & 0.45 & 0.65 & 0.02 & 0.30 & 0.30 & 0.60 & 0.40 & 0.46 & 1.00 \\
\hline
\end{tabular}

\section{Discussion of Results}

The following table summarizes our findings.

Table 5. Result Estimates

\begin{tabular}{|l|l|l|l|l|l|l|l|l|l|l|}
\hline & \multicolumn{2}{|l}{$\begin{array}{l}\text { Energy } \\
\text { Industry }\end{array}$} & \multicolumn{2}{l}{$\begin{array}{l}\text { Agriculture } \\
\text { Industry }\end{array}$} & \multicolumn{2}{l|}{$\begin{array}{l}\text { Manufacturing } \\
\text { Industry }\end{array}$} & \multicolumn{2}{l|}{$\begin{array}{l}\text { Mining } \\
\text { Industry }\end{array}$} & \multicolumn{2}{l|}{ Technology } \\
Industry
\end{tabular}

Notes: $* * *, * *$ and $*$ denote respectively statistical significance at $1 \%, 5 \%$ and $10 \%$ levels.

FE/RE means based on the Hausman test which result was used.

$\mathrm{F}$ is FOCAC and $\mathrm{F}+\mathrm{B}$ is FOCAC+BRI

For the period where only FOCAC was being implemented the energy sector showed a 
negative relationship with imports even though it was not significant. This is changed when the BRI was introduced to not only have a positive interaction with trade but is significant at $1 \%$. This shows that imports are playing a key role in the development of the energy sector. In the period of FOCAC+BRI, we accept hypothesis 1 proposed and reject it for the prior period. On the other hand, from the results, there is a relationship between the exports to China and energy consumption. This is contrary to the initial prediction that there is no significant relationship between these two. This may be due to the effect trade has on production which increases consumption.

As predicted, there is a positive and significant relationship between imports and the agriculture industry at $1 \%$ and $10 \%$ significant level respectively for the two periods under consideration. We, therefore, accept the hypothesis for both periods which is proof that China has been bringing goods that have increased agricultural production as also supported by (Habiyaremye, 2016). Interestingly, the exports show a different trend which is opposite to the predicted hypothesis. The exports in the agriculture sector show that before FOCAC there was no significant relationship even though it was negative and it becomes significant after the BRI was introduced. According to (Eisenman, 2012; Maswana, 2007; C. Mlambo et al., 2016) the level of resources in the primary sector of the country will affect how they benefit from this trade which is one possible explanation why exports haven't fully benefited the agriculture industry where production is still low. (Maswana, 2007; C. Mlambo et al., 2016).

The imports from China are unfortunately negatively and significantly affecting the local manufacturing industry at $5 \%$ and $1 \%$ in the two periods respectively. Even though the initial prediction expected that capital goods being imported would bring more benefits, the imported finished goods have brought a negative more impact on industries. This is because they are not only cheaper but they are better substitutes compared to what is already on the market as also concluded by (Eisenman, 2012) who finds the manufacturing sector of China as more competitive. On the other hand, the exports from the manufacturing sector positively affect the industry as predicted. Even though the contribution is only significant during the FOCAC era and just positive afterward this is a sign that if well utilized the manufacturing industry would greatly benefit from exporting to the niches in China.

As predicted the mining sector is negatively related to imports even though this relationship is not significant. However, in both periods we see the coefficient decreasing which is proof that when the continent imports minerals it negatively affects their industry as also supported by (Busse et al., 2016). This is further supported by the positive relationship between exports and minerals which is significant at $1 \%$ during the FOCAC+OBOR era. Based on the regression run, minerals have the highest coefficient with exports showing how much they benefit from trade with China. The increased significance in minerals can be further supported by the growing significance of mines in the deals including their role in the swap payments for various projects and financial loans. Also, China has a high demand for minerals which their local mines cannot meet (Gamache \& Jones, 2013) hence African minerals which are the continent's treasure remain in high demand to the economy of China.

In both periods the imports failed to have a significant impact on the technological 
development of Africa. Imports in the second era had a negative relationship which again wasn't significant. This is a factor worth looking at in the future to ensure maximum gains are obtained directly from technically advanced equipment as well as indirectly through spillovers. The negative and significant relationship with exports in the second era shows that the technology industry is not benefitting when exports are being made and when they grow as well.

\section{Conclusion}

The study found that there is a positive impact on the agriculture and energy industries from the imports that come from China. These two are heavily dependent on the advanced equipment which China offers at cheaper prices with good quality which was one of the biggest barriers from the other trade partners. The manufacturing sector is negatively affected by imports from China which is something that has to be addressed through policies that protect the local manufacturers who are failing to beat the competition from China.

For exports, the study found a positive relationship with the mining sector. This shows that the minerals from Africa are a key component in the trade. However (Rahman et al., 2017) cautions the continent that even though the contribution to the economy of the minerals is high it remains questionable how sustainable the rate of mining is. Another very important finding is the positive relationship with the manufacturing industry which shows the potential that this industry has to enjoy niche markets in the Chinese economy saturated by manufacturers of different. On the other hand, the agriculture industry showed a negative relationship with exports. This is something that should be looked at especially as the continent's agriculture sector has been a backbone to most economies and has been exporting high volumes of products to China yet the benefits aren't bringing a much-needed positive impact on the industry.

The results of this study have proven that bilateral relations are important in the contribution trade has on industries. With the continent benefiting from FOCAC, there are even more opportunities and higher potential from the combination of FOCAC and BRI. The fact that BRI is working in selected countries that are acting as entry channels for trade and development it is still expected that this will not only benefit the countries concerned but will spill into the rest of the continent. This study makes use of those six countries together with the rest of the countries grouped to show the significant role of trade. The fact that China is narrowing its focus to selected countries in the BRI is likely not to affect the benefits to the continent if they work together with these countries in promoting the agenda of the continent and the long-term goals set at the region's Africa Union summits. The improved terms of trade which have made some industries like mining more involved in the trade have resulted in a positive effect of trade on the industry which is reflected in the GDP as well. This is something that has to also be replicated in other industries that are still not performing well especially the technology industry which is lagging not only in trade but on the continent as a whole.

For future studies, we recommend that one can look at the technology industry which still needs to be built across the continent. 


\section{References}

Adeline, A., \& Moussa, R. K. (2020). Simultaneous Equations Model with Non-Linear and Linear Dependent Variables on Panel Data. Theoretical Economics Letters, 10(01), 69-89.

https://doi.org/10.4236/tel.2020.101005

Aly, M. (2019). The China-Africa Relations: Between the Development Cooperation and Economic Diplomacy. Open Journal of Political Science, 9, 7.

https://doi.org/10.4236/ojps.2019.92016

Anedo, O. (2012). China - Africa culture differences in business relations. African Journal of Political Science and International Relations, 6(4), 4.

https://doi.org/10.5897/AJPSIR11.130

Asante, R. (2018). China and Africa Model of South-South Cooperation? China Quarterly of International Strategic Studies, 4(2), 21. https://doi.org/10.1142/S2377740018500124

Biswas, A. K., \& Tortajada, C. (2018). How new Silk Road will cement China as major trading partner for Africa. THE CONVERSATION, 2018, 4.

Bodomo, A. (2019). Africa-China-Europe relations: Conditions and conditionalities. Journal of International Studies, 12(4), 15. https://doi.org/10.14254/2071-8330.2019/12-4/8

Bulletin, E. E. (2017). Does trade play a role in helping to explain productivity growth? Boxes, 7, 1.

Burinskiene, A. (2012). The Theoretical Link Between Trade and Productivity. https://doi.org/10.2507/daaam.scibook.2012.25

Busse, M., Erdogan, C., \& Mühlen, H. (2016). China's Impact on Africa - The Role of Trade, FDI and Aid. KYKLOS, 69(2), 36. https://doi.org/10.1111/kykl.12110

Chen, K., Xu, S., \& Haralambides, H. (2019). Determining hub port locations and feeder network designs: The case of China-West Africa trade. Transport Policy, 86(2020), 14. https://doi.org/10.1016/j.tranpol.2019.12.002

Dai, H., \& Xu, J. (2013). Collaborative design of RFID systems for multi-purpose supply chain applications. Journal of Systems Science and Systems Engineering, 22(2), 152-170. https://doi.org/10.1007/s11518-013-5214-9

Drummond, P., \& Liu, E. X. (2015). Africa's Rising Exposure to China: How Large Are Spillovers Through Trade? International Advances in Economic Research, 21(3), 317-334. https://doi.org/10.1007/s11294-015-9537-9

Eisenman, J. (2012). China-Africa Trade Patterns: causes and consequences. Journal of Contemporary China, 21(77), 18. https://doi.org/10.1080/10670564.2012.684964

Esterhuyse, H., \& Burgess, M. (2014). Forum: Engaging the environment in the relationship between China and Africa. African East-Asian Affairs | The China Monitor, 1(March), 12. https://doi.org/10.7552/0-1-122 


\section{Macrothink Institute $^{\mathrm{TM}}$}

Foo, N., Lean, H. H., \& Salim, R. (2019). The impact of China's one belt one road initiative on international trade in the ASEAN region. The North American Journal of Economics and Finance, 101089. https://doi.org/10.1016/j.najef.2019.101089

Gagne, O. S. (2018). Cultural Distance and FDI: China Africa Perspective. Open Journal of Business and Management, 6, 18. https://doi.org/10.4236/ojbm.2018.62028

Gamache, L., Alexander, H., \& Jones, L. (2013). China's Trade And Investment Relationship With Africa. USITC Executive Briefings on Trade.

Geda, A. (2006). The Impact of China and India on Africa: Trade FDI and the African Manufacturing Sector. African Economic Research Consortium, 36.

Guo, P., \& Shen, Y. (2016). The impact of Internet finance on commercial banks' risk taking: evidence from China. China Finance and Economic Review, 4(1).

https://doi.org/10.1186/s40589-016-0039-6

Habiyaremye, A. (2016). Is Sino-African trade exacerbating resource dependence in Africa? Structural Change and Economic Dynamics, 37, 1-12.

https://doi.org/10.1016/j.strueco.2015.11.003

Hammon, A., \& Zinn, S. (2020). Multiple imputation of binary multilevel missing not at random data. Journal of the Royal Statistical Society: Series C (Applied Statistics), 69(3), 547-564. https://doi.org/10.1111/rssc.12401

Harlies, A. (2019). The Paradox of Sino-South Africa Relations.

Havrlant, D., \& Hušek, R. (2011). Models of Factors Driving the Czech Export. Prague Economic Papers, 20(3), 195-215. https://doi.org/10.18267/j.pep.396

He, Y. (2013). Does China's trade expansion help African development? - an empirical estimation. China Economic Review, 26, 28-38.

https://doi.org/10.1016/j.chieco.2013.04.001

Hill, T. D., Davis, A. P., Roos, J. M., \& French, M. T. (2019). Limitations of Fixed-Effects Models for Panel Data. Sociological Perspectives, 26.

https://doi.org/10.1177/0731121419863785

Ibrahim, I. (2017). Impact of Sino-Africa Economic Relations on the Ghanaian Economy: The Case of Textiles. International Journal of Innovation and Economic Development, 3(1), 20. https://doi.org/10.18775/ijied.1849-7551-7020.2015.31.2001

Ibrahim, I. (2018). China Africa Relations: Trade Or Gold Rush In Ghana? International Journal of Economics, Commerce and Management, VI(1), 19.

Kea, S., Li, H., Shahriar, S., Abdullahi, N. M., Phoak, S., \& Touch, T. (2019). Factors Influencing Cambodian Rice Exports: An Application of the Dynamic Panel Gravity Model. Emerging Markets Finance and Trade, 55(15), 3631-3652.

https://doi.org/10.1080/1540496X.2019.1673724 
Kilic, C., Yusecan, M., \& Ozekicioglu, H. (2019). Relationship Between Migration and Unemployment: Panel Data Analysis for Selected OECD Countries. Montenegrin Journal of Economics, 15(3), 101-111. https://doi.org/10.14254/1800-5845/2019.15-3.7

Lyons, M., Brown, A., \& Li, Z. (2013). ASR Forum: Engaging With African Informal Economies. African Studies Review, 56(3), 23. https://doi.org/10.1017/asr.2013.80

Maswana, J.-C. (2007). China-Africa's Emerging Economic Links: A review under the Core-Periphery perspective. Paper presented at the World Association for the Political Economy (WAPE), Shimane, Japan.

Mhaka, S., \& Jeke, L. (2018). An evaluation of the trade relationships between South Africa and China: An empirical review 1995-2014. South African Journal of Economic and Management Sciences, 21(1), 15. https://doi.org/10.4102/sajems.v21i1.2106

Mlambo, C., Kushamba, A., \& Simawu, M. B. (2016). China-Africa Relations: What Lies Beneath? The Chinese Economy, 49(4), 21.

https://doi.org/10.1080/10971475.2016.1179023

Mlambo, D. N., Mlambo, V. H., \& Mubecua, M. A. (2018). The Rise of Chinese Investments in Africa: For Whose Benefit? Journal of Economics and Behavioral Studies, 10(4), 7.

https://doi.org/10.22610/jebs.v10i4(J).2409

Monson, J., \& Rupp, S. (2013). Africa and China: New Engagements, New Research. African Studies Review, 56(1), 23. https://doi.org/10.1353/arw.2013.0032

Moussa, R. K. (2019). Heteroskedasticity in One-Way Error Component Probit Models. Econometrics, 7(3), 35. https://doi.org/10.3390/econometrics7030035

Rahman, D. H. A. A., Majidi, N., Huwaina, F., Harun, N. F. A., \& Kasuma, J. (2017). Economic Growth in Malaysia: A Causality Study on Macroeconomics Factors. Journal of Entrepreneurship and Business, 5(2), 9. https://doi.org/10.17687/JEB.0502.06

Sen, S. (2010). International Trade Theory and Policy: A Review of the Literature. Levy Economics Institute of Bard College, Working Paper 635, 24.

https://doi.org/10.2139/ssrn.1713843

Tang, D., \& Gyasi, K. B. (2012). China - Africa Foreign Trade Policies: the Impact of China's Foreign Direct Investment (FDI) Flow on Employment of Ghana. Energy Procedia, 16, 553-557. https://doi.org/10.1016/j.egypro.2012.01.089

Taylor, S. L. (1986). Analysing financial statements: How many variables should we look at? The Securities Institute Journal, 1(April), 3.

Titiloye Ademola, O., Bankole, A. S., \& Adewuyi, A. O. (2009). China-Africa Trade Relations: Insights from AERC Scoping Studies. The European Journal of Development Research, 21(4), 485-505. https://doi.org/10.1057/ejdr.2009.28

Tsokalida, E. E., \& Jun, Y. (2019). The Impact of FOCAC on African countries Trade Flows. International Journal of Science and Business, 3(3), 9. 


\section{Macrothink}

https://doi.org/10.5281/zenodo.2647400

Van Staden, C., Alden, C., \& Wu, Y.-S. (2018). IN THE DRIVER'S SEAT? AFRICAN AGENCY AND CHINESE POWER AT FOCAC, THE AU AND THE BRI. South African Institute of International Affairs, 286(September), 32.

Wang, G., Fu, C., Liu, J., Zhang, L., Oduor, A. M. O., Mojo, D., \& Balehegn, M. (2018). Promoting the Nexus Approach of Climate, Ecosystems and Livelihoods in Africa through China-Africa Cooperation. Journal of Resources and Ecology, 9(3), 4.

https://doi.org/10.5814/j.issn.1674-764x.2018.03.002

Wang, K., Gou, Q., Sun, J., \& Yue, X. (2012). Coordination of a fashion and textile supply chain with demand variations. Journal of Systems Science and Systems Engineering, 21(4), 461-479. https://doi.org/10.1007/s11518-012-5205-2

Yu, S., Qian, X., \& Liu, T. (2019). Belt and road initiative and Chinese firms' outward foreign direct investment. Emerging Markets Review, 41, 100629.

https://doi.org/10.1016/j.ememar.2019.100629

Zhai, F. (2018). China's belt and road initiative: A preliminary quantitative assessment. Journal of Asian Economics, 55, 84-92. https://doi.org/10.1016/j.asieco.2017.12.006

Zoumara, B., \& Ibrahim, A.-R. (2013). China-Africa Relations: Looking Beyond the Critics. Pambazuka News. p. 3. [Online] Available: http://pambazuka.org/en/category/features/87735

\section{Copyright Disclaimer}

Copyright for this article is retained by the author(s), with first publication rights granted to the journal.

This is an open-access article distributed under the terms and conditions of the Creative Commons Attribution license (http://creativecommons.org/licenses/by/4.0/). 